\title{
Dissecting Transmetalation Reactions at the Molecular Level: Phenyl Transfer in Metal Borate Complexes
}

Thomas Auth, ${ }^{\dagger}$ Konrad Koszinowski, ${ }^{*, \dagger}$ and Richard A. J. O’Hair, ${ }^{*,+,}$

${ }^{\dagger}$ Insitut für Organische und Biomolekulare Chemie, Universität Göttingen, Tammannstraße 2, 37077 Göttingen, Germany

${ }^{\ddagger}$ School of Chemistry and Bio21 Molecular Science and Biotechnology Institute, University of Melbourne, 30 Flemington Rd, Parkville, Victoria 3010, Australia

E-mail: konrad.koszinowski@chemie.uni-goettingen.de, rohair@unimelb.edu.au

\section{Supporting Information}

\section{Table of Contents}

1) NMR spectra $\quad S 2$

2) Mass spectra, breakdown curves, molecular structures and energy diagrams $\quad S 4$

3) Author contributions $\quad$ S22 


\section{1) NMR spectra}
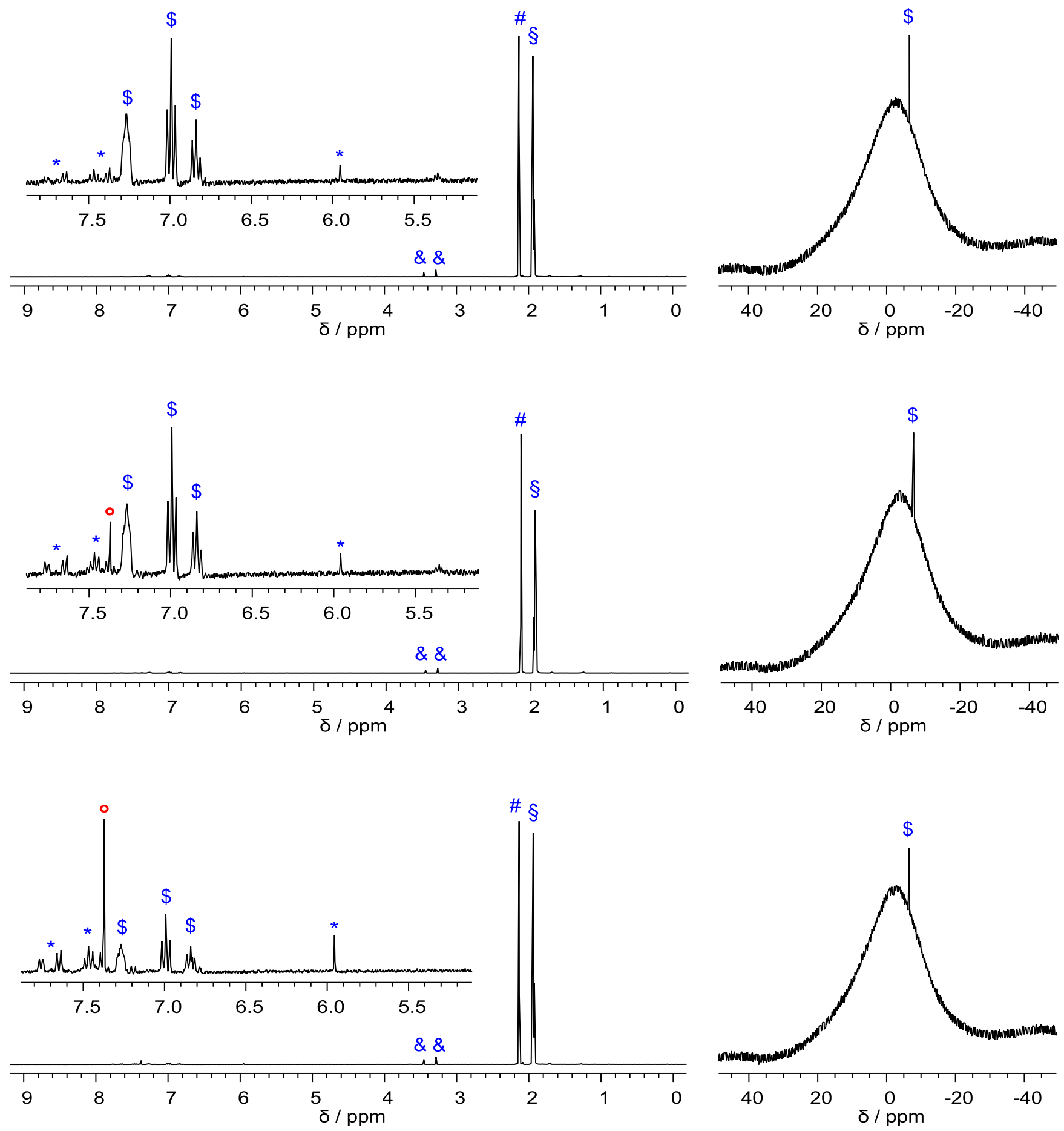

Figure S1. Condensed phase experiments showing transmetalation from B to Ag: ${ }^{1} \mathrm{H}$ NMR spectra $(300 \mathrm{MHz}$, left) and ${ }^{11} \mathrm{~B}\left\{{ }^{1} \mathrm{H}\right\} \mathrm{NMR}$ spectra $\left(96 \mathrm{MHz}\right.$, right) of aliquots of a solution of $\left(\mathrm{CH}_{3} \mathrm{OCH}_{2} \mathrm{CH}_{2} \mathrm{OCH}_{3}\right)_{3} \mathrm{Li}\left(\mathrm{BPh}_{4}\right)$ and $\mathrm{Ag}(\mathrm{OTf})$ in acetonitrile- $d_{3}(\sim 2: 1,0.2 \mathrm{mM}$ for the lithium salt) removed after stirring at room temperature for $1 \mathrm{~h}$ (top), after additional stirring at $70{ }^{\circ} \mathrm{C}$ for $1 \mathrm{~h}$ (middle) and after further stirring at $70{ }^{\circ} \mathrm{C}$ for $\sim 12 \mathrm{~h}$ (bottom). The insets in the left spectra show an expansion of the region from 5-8 ppm. The broad underlying signal in the right spectra originates from the borosilicate glass NMR tube. §: solvent signal; \#: $\mathrm{H}_{2} \mathrm{O} ;$ \&: $\mathrm{CH}_{3} \mathrm{OCH}_{2} \mathrm{CH}_{2} \mathrm{OCH}_{3}$ signals; *: impurities from the lithium salt; $\$: \mathrm{BPh}_{4}{ }^{-}$signals; ${ }^{\circ}$ : benzene. 

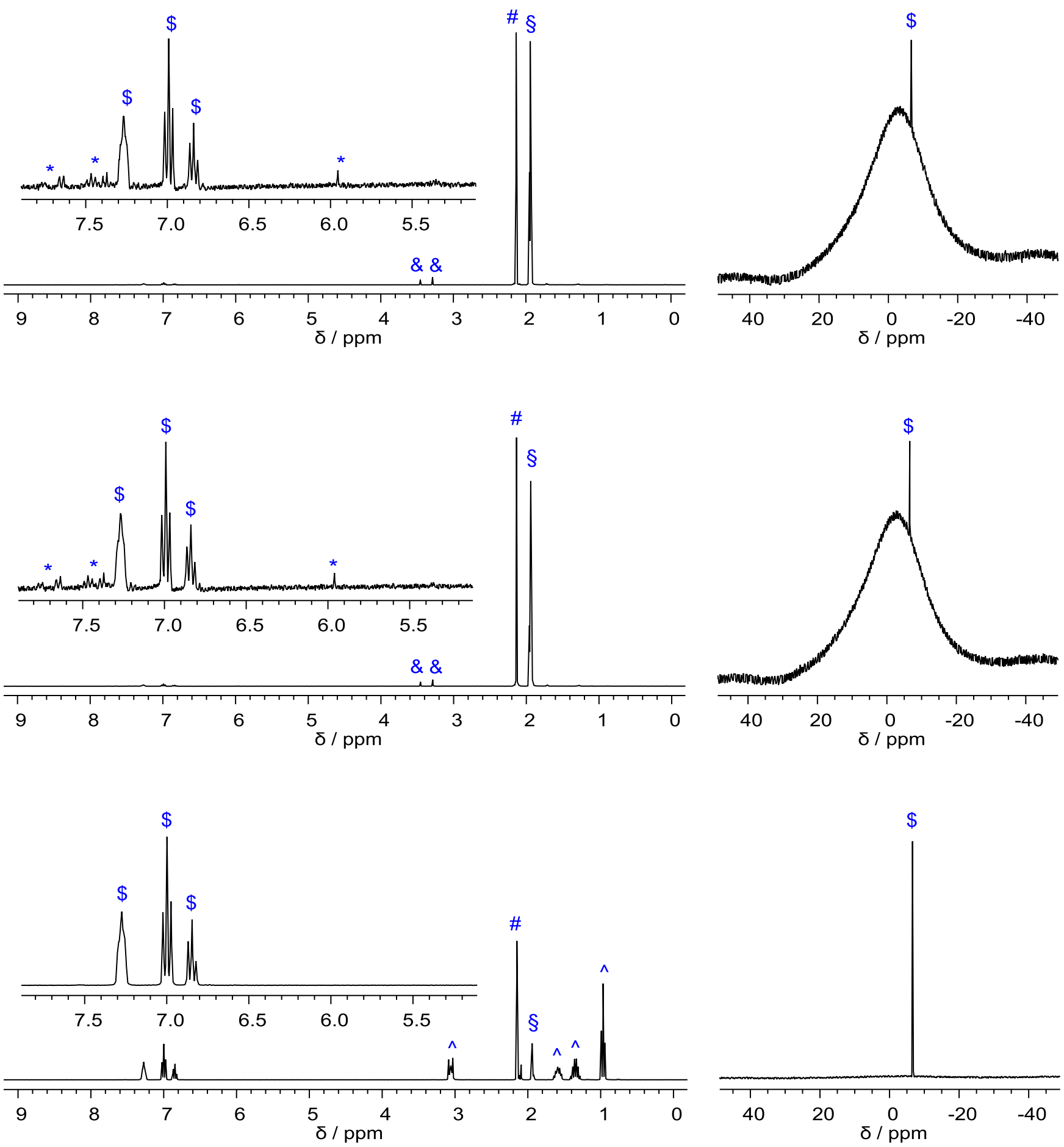

Figure S2. Condensed phase experiments showing transmetalation from $B$ to Li does not occur: ${ }^{1} \mathrm{H}$ NMR spectra (300 MHz, left) and ${ }^{11} \mathrm{~B}\left\{{ }^{1} \mathrm{H}\right\} \mathrm{NMR}$ spectra $(96 \mathrm{MHz}$, right) of aliquots of a solution of $\left(\mathrm{CH}_{3} \mathrm{OCH}_{2} \mathrm{CH}_{2} \mathrm{OCH}_{3}\right)_{3} \mathrm{Li}\left(\mathrm{BPh}_{4}\right)$ in acetonitrile- $d_{3}(0.2 \mathrm{mM})$ removed after stirring at room temperature for $1 \mathrm{~h}$ (top) and after additional stirring at $70{ }^{\circ} \mathrm{C}$ for $\sim 13 \mathrm{~h}$ (middle). ${ }^{1} \mathrm{H}$ and ${ }^{11} \mathrm{~B}\left\{{ }^{1} \mathrm{H}\right\} \mathrm{NMR}$ spectra were also measured for a solution of $\left(\mathrm{NBu}_{4}\right)\left(\mathrm{BPh}_{4}\right)$ in acetonitrile- $d_{3}$ (bottom) in order to unambiguously identify signals corresponding to $\mathrm{BPh}_{4}{ }^{-}$. The insets in the left spectra show an expansion of the region from 5-8 ppm. The broad underlying signal in the right spectra originates from the borosilicate glass NMR tube. §: solvent signal; \#: $\mathrm{H}_{2} \mathrm{O}$; \&: $\mathrm{CH}_{3} \mathrm{OCH}_{2} \mathrm{CH}_{2} \mathrm{OCH}_{3}$ signals; *: impurities from the lithium salt; $\$$ : $\mathrm{BPh}_{4}{ }^{-}$signals; ${ }^{\wedge}: \mathrm{NBu}_{4}{ }^{+}$signals. 
2) Mass spectra, breakdown curves, molecular structures and energy diagrams

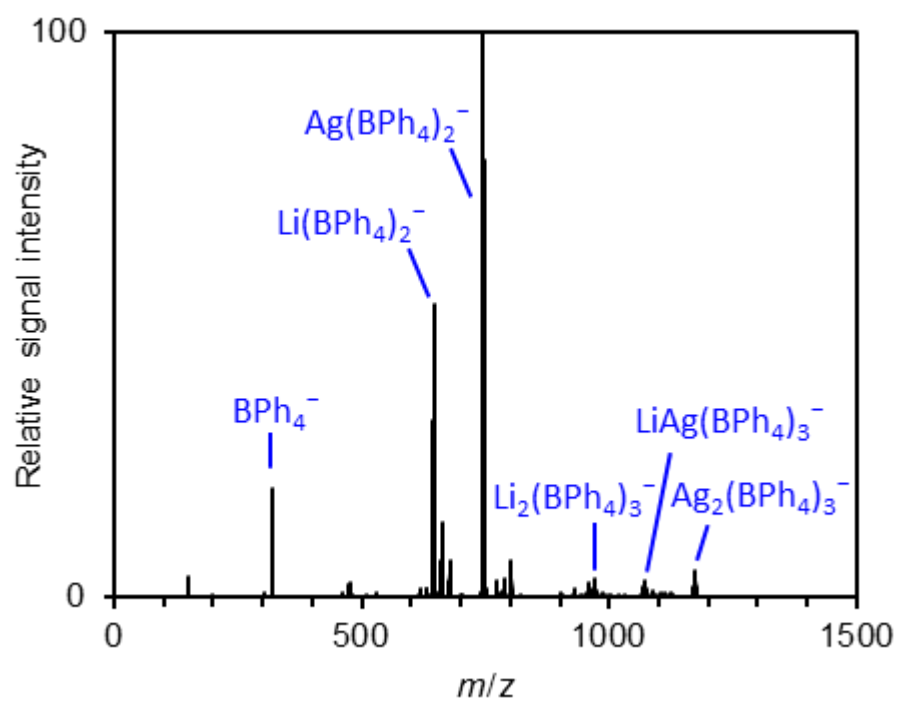

Figure S3. Negative-ion mode ESI mass spectrum of a solution of $\mathrm{Ag}(\mathrm{OTf})$ and $\mathrm{Li}\left(\mathrm{BPh}_{4}\right)$ in $\mathrm{CH}_{3} \mathrm{CN}$.

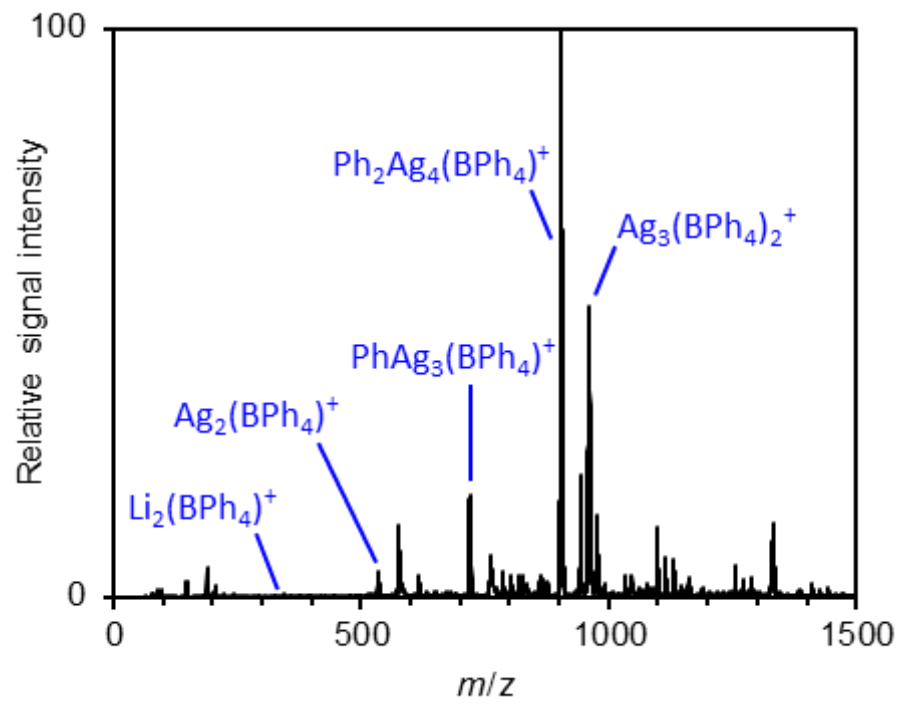

Figure S4. Positive-ion mode ESI mass spectrum of a solution of $\mathrm{Ag}(\mathrm{OTf})$ and $\mathrm{Li}\left(\mathrm{BPh}_{4}\right)$ in $\mathrm{CH}_{3} \mathrm{CN}$ with increased flow rate of the nitrogen drying gas. 


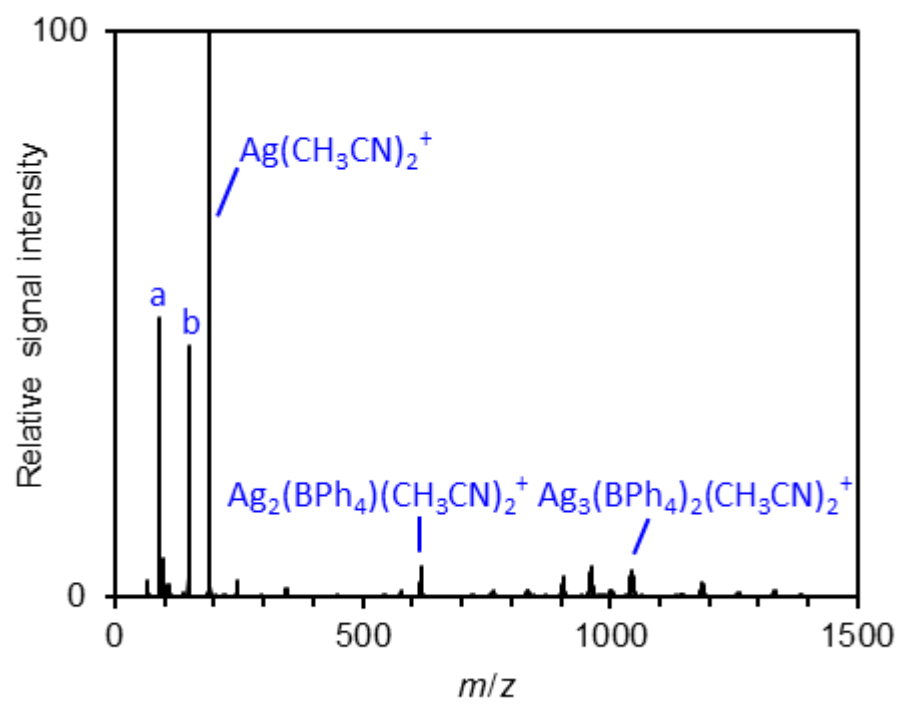

Figure S5. Positive-ion mode ESI mass spectrum of a solution of $\mathrm{Ag}(\mathrm{OTf})$ and $\mathrm{Li}\left(\mathrm{BPh}_{4}\right)$ in $\mathrm{CH}_{3} \mathrm{CN}$ without increased flow rate of the nitrogen drying gas. a: $\mathrm{Li}\left(\mathrm{CH}_{3} \mathrm{CN}\right)_{2}{ }^{+}, \mathrm{b}: \mathrm{Ag}\left(\mathrm{CH}_{3} \mathrm{CN}\right)^{+}$.

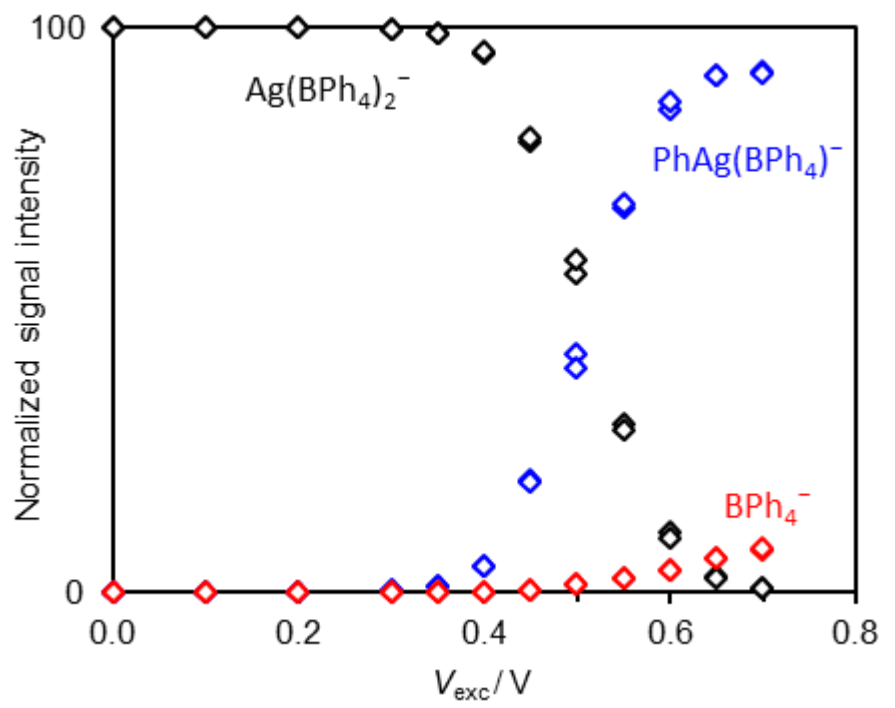

Figure S6. Normalized signal intensities of $\mathrm{Ag}\left(\mathrm{BPh}_{4}\right)_{2}{ }^{-}$and its fragment ions as function of the excitation voltage $V_{\text {exc }}$. 


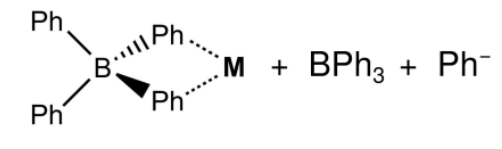

$$
\mathrm{Ag}-\mathrm{Ph}+\mathrm{BPh}_{3}+\mathrm{Ph}^{-}
$$

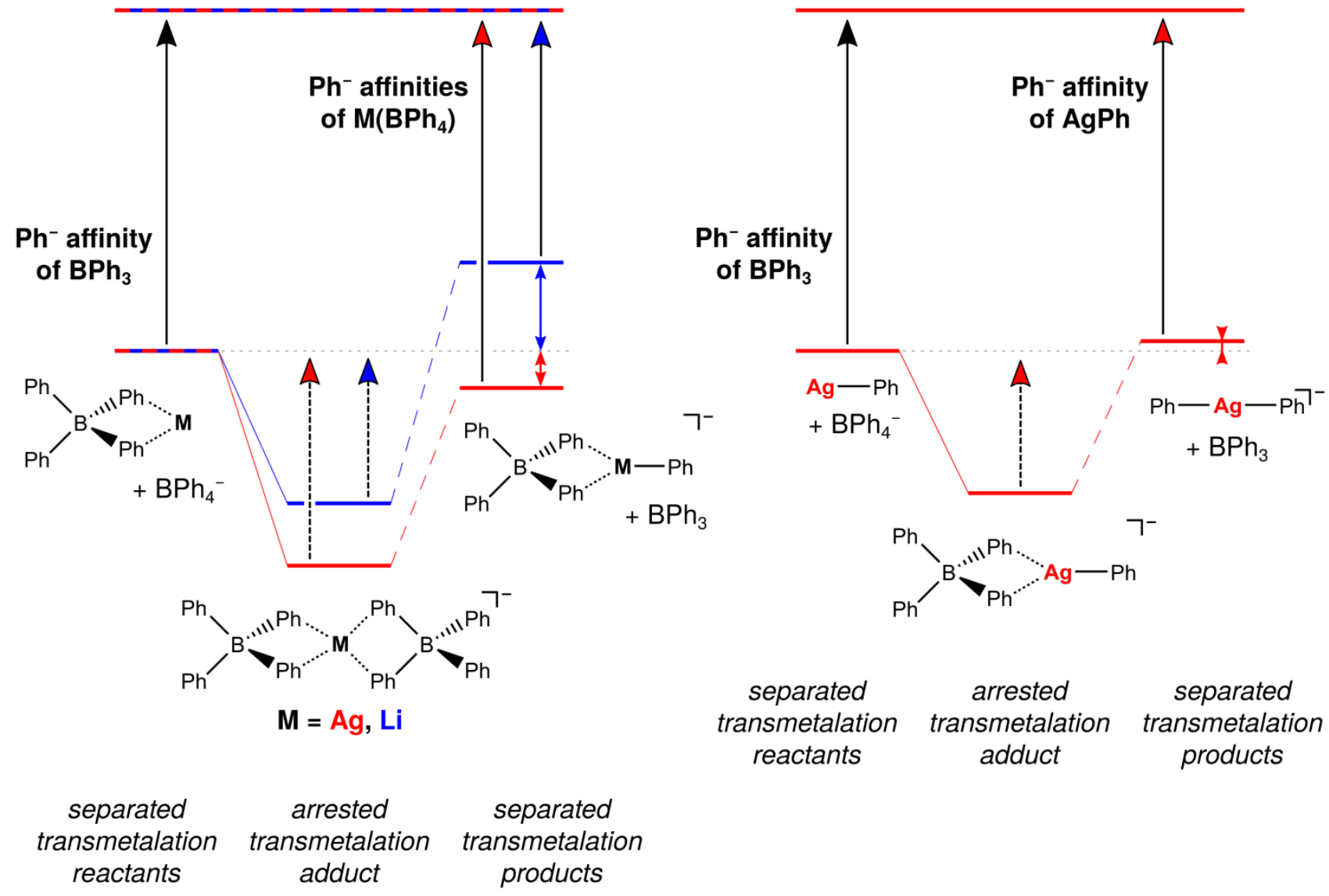

Figure S7. Thermochemical cycles for the transmetalation reactions of the arrested transmetalation adducts $\mathrm{M}\left(\mathrm{BPh}_{4}\right)_{2}^{-}$(left) and $\mathrm{PhAg}\left(\mathrm{BPh}_{4}\right)^{-}$(right) toward the corresponding separated transmetalation products $(\mathrm{M}=\mathrm{Ag}$ in $\mathrm{red}, \mathrm{Li}$ in blue). These cycles reveal the individual contributions to the reaction energies of the transmetalation pathways (dashed lines): In each case, the energy gap between the separated transmetalation reactants and the separated transmetalation products (indicated by a double arrow) is given by the difference of the $\mathrm{Ph}^{-}$affinities of $\mathrm{BPh}_{3}$ and the respective MX complex $\left(\mathrm{X}=\mathrm{BPh}_{4}{ }^{-}, \mathrm{Ph}^{-}\right)$. The sum of this difference and the energy for the direct dissociation of the arrested transmetalation adduct, i. e., the $\mathrm{BPh}_{4}{ }^{-}$affinity of $\mathrm{MX}$ (indicated by a dashed arrow), determines the reaction energy of the transmetalation pathway. The thermochemical cycles are based on the $\Delta H^{\rho}$ values obtained from DSD-PBEP86-D3BJ/maug-cc-pVTZ//PBEh-3c calculations. 
Table S1. Reaction enthalpies $\Delta H^{0}$ for the heterolytic dissociation of $X-P h$ bonds $(X=B, A g, L i)$, i. e., phenyl anion affinities, relevant to the unimolecular reactivity of $\mathrm{M}\left(\mathrm{BPh}_{4}\right)_{2}^{-}(\mathrm{M}=\mathrm{Ag}, \mathrm{Li})$ and $\mathrm{PhAg}\left(\mathrm{BPh}_{4}\right)^{-}$complexes. The values were obtained from DSD-PBEP86-D3BJ/maug-cc-pVTZ//PBEh-3c calculations. In addition, the corresponding phenyl anion affinities of $\mathrm{Ag}^{+}$and $\mathrm{Li}^{+}$are given for comparison. The values in brackets are previously calculated phenyl anion affinities of $\mathrm{Ag}^{+}$and $\mathrm{Li}^{+}$by Tsipis and Gkarbounis. ${ }^{a}$

Reaction $\Delta H^{0} / \mathrm{kJ} \mathrm{mol}^{-1}$

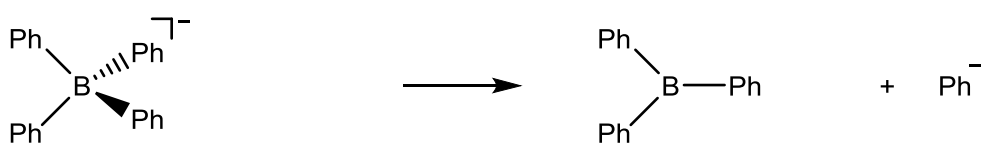

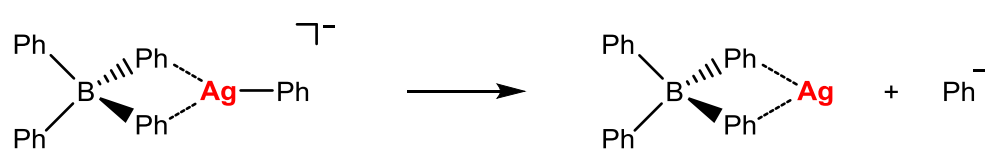

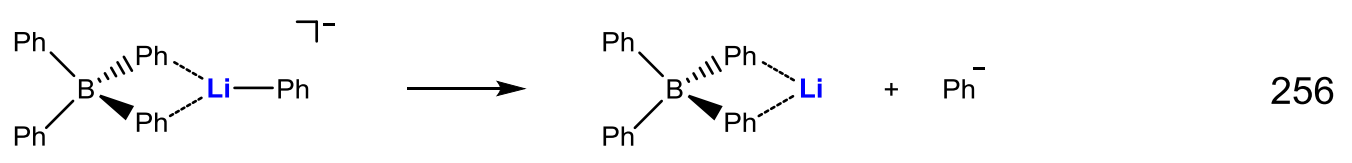
$\mathrm{Ph}-\mathrm{Ag}-\mathrm{Ph}^{-}$
$\longrightarrow \mathrm{Ph}-\mathrm{Ag}$
$+\mathrm{Ph}^{-}$

\begin{tabular}{|c|c|c|c|}
\hline $\mathrm{Ag}-\mathrm{Ph}$ & $\mathrm{Ag}^{+}$ & $+\mathrm{Ph}^{-}$ & 849 (854) \\
\hline $\mathrm{Li}-\mathrm{Ph}$ & $\mathrm{Li}^{+}$ & $+\mathrm{Ph}^{-}$ & $670(678)$ \\
\hline
\end{tabular}

${ }^{a}$ Tsipis, A. C.; Gkarbounis, D. N. J. Mol. Model. 2015, 21, 153.
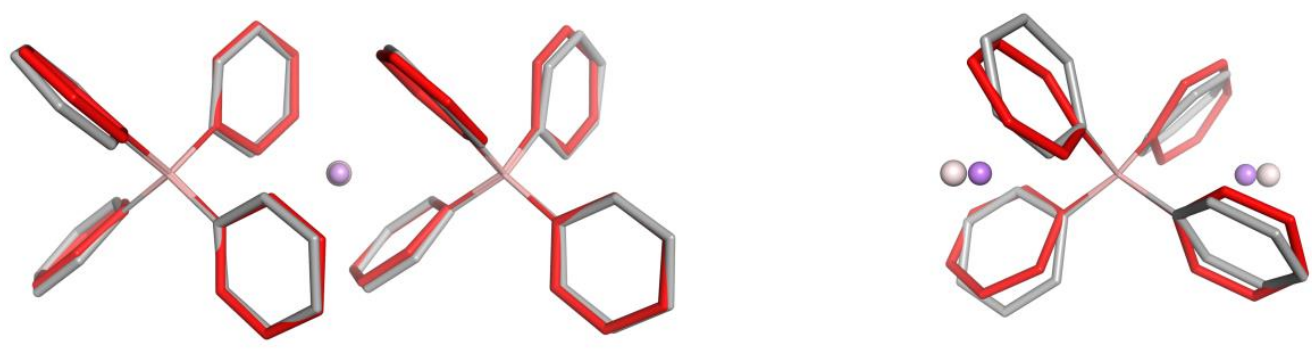

Figure S8. Superimposed molecular geometries of $\mathrm{Ag}\left(\mathrm{BPh}_{4}\right)_{2}^{-}$and $\mathrm{Li}\left(\mathrm{BPh}_{4}\right)_{2}^{-}$(left) and of $\mathrm{Ag}_{2}\left(\mathrm{BPh}_{4}\right)^{+}$and $\mathrm{Li}_{2}\left(\mathrm{BPh}_{4}\right)^{+}$(right). The structures were obtained from PBEh-3c geometry optimizations. The phenyl groups of the silver and lithium complexes are shown in gray and red, respectively. The metal centers of the anionic complexes are located at the same position. $\mathrm{H}$ atoms are omitted for clarity. 


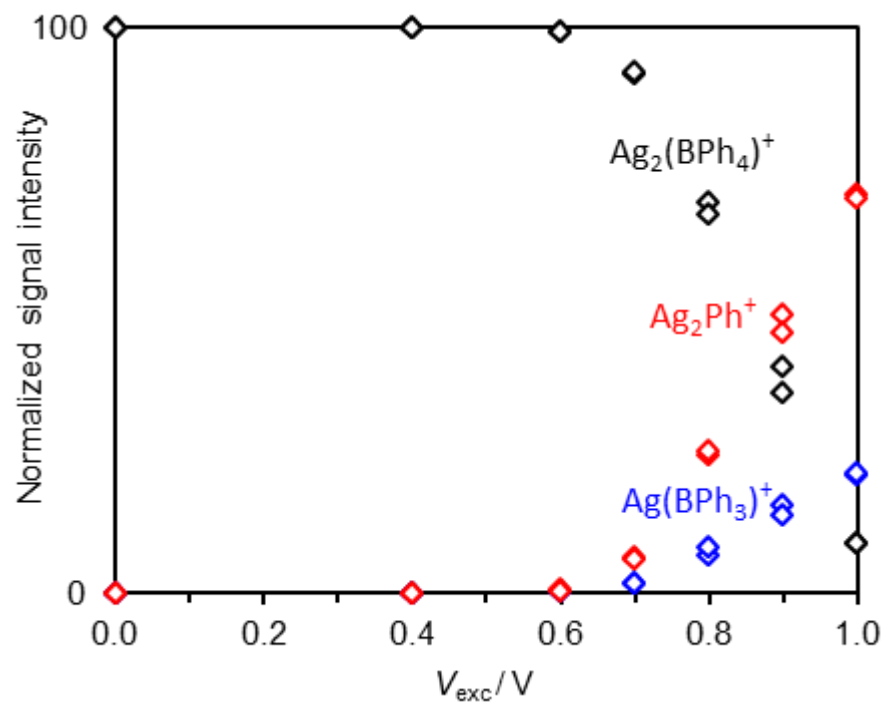

Figure S9. Normalized signal intensities of $\mathrm{Ag}_{2}\left(\mathrm{BPh}_{4}\right)^{+}$and its fragment ions as function of the excitation voltage $V_{\text {exc. }}$

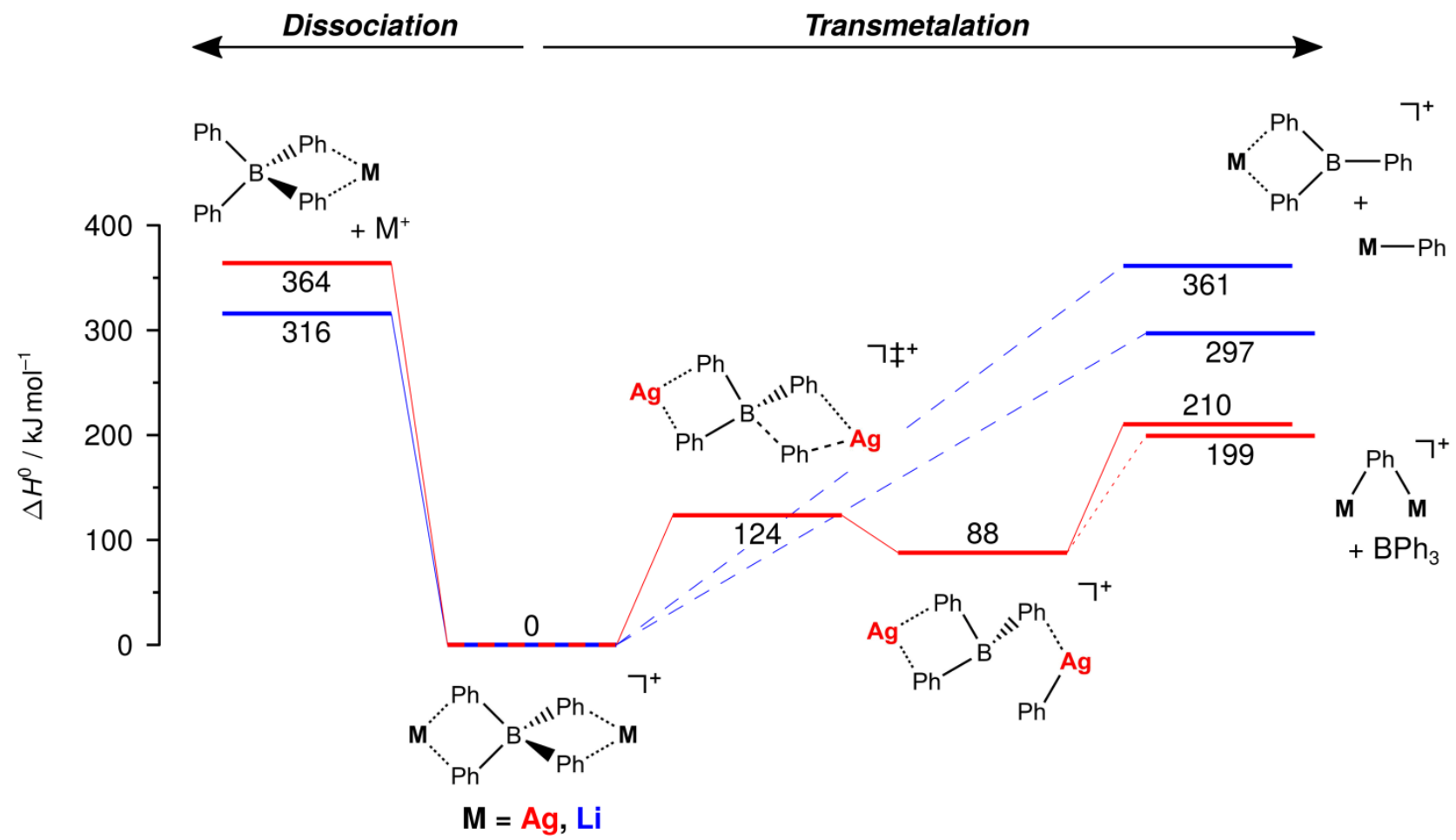

Figure S10. Energy diagrams for the unimolecular reactivity (dissocation vs. alternative transmetalation pathway to that shown in Figure 2, bottom) of $\mathrm{M}_{2}\left(\mathrm{BPh}_{4}\right)^{+}$obtained from DSD-PBEP86-D3BJ/maug-cc-pVTZ//PBEh-3c calculations $(\mathrm{M}=\mathrm{Ag}$ in red, $\mathrm{Li}$ in blue). For $\mathrm{M}=\mathrm{Li}$, only the thermochemistry was determined for the transmetalation pathways (blue dashed lines). The red dotted line corresponds to path D of Figure S11. 


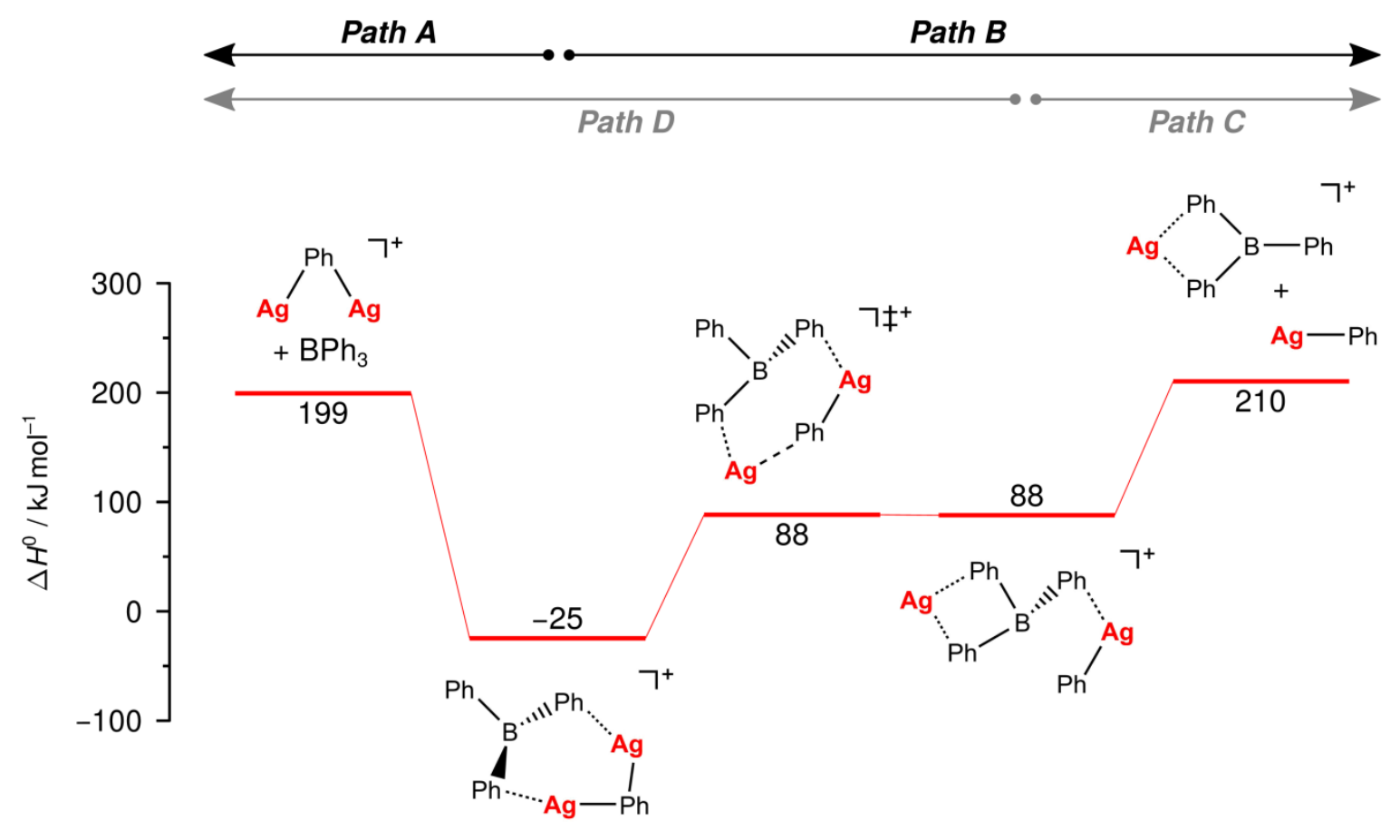

Figure S11. Energy diagram for the isomerization of $\mathrm{PhAg}_{2}\left(\mathrm{BPh}_{3}\right)^{+}$and the dissociation of each isomer obtained from DSD-PBEP86-D3BJ/maug-cc-pVTZ//PBEh-3c calculations. Path A and B $\{C$ and D $\}$ correspond to the formation of transmetalation products starting from intermediate $\mathrm{PhAg}_{2}\left(\mathrm{BPh}_{3}\right)^{+}\left\{(\mathrm{PhAg})\left(\mathrm{BPh}_{3}\right) \mathrm{Ag}^{+}\right\}(\mathrm{cf}$. Figures 2 and S10, respectively).
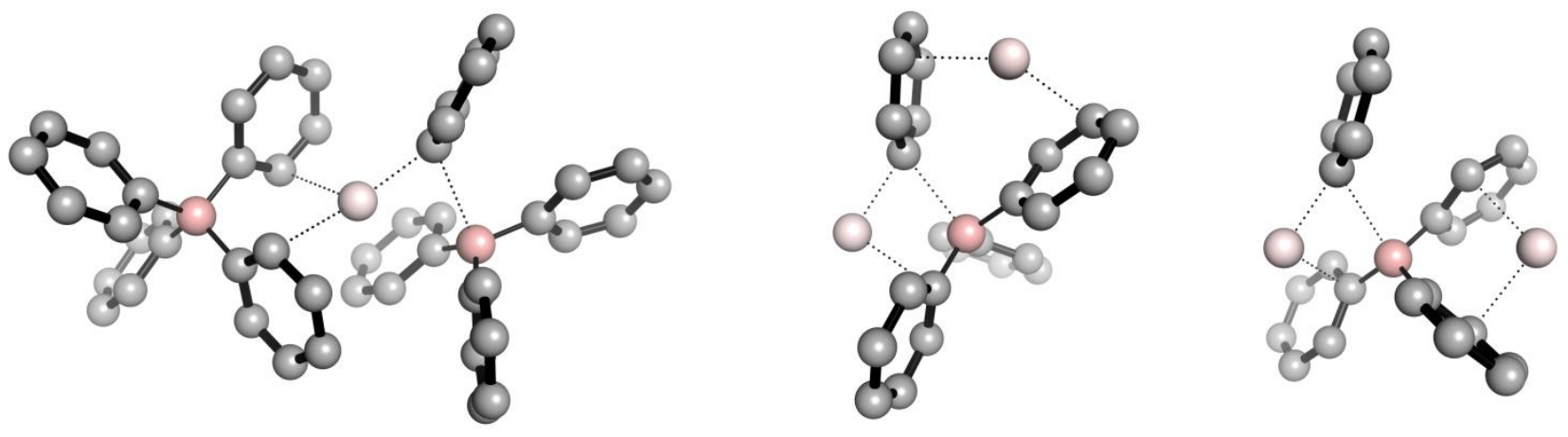

Figure S12. Transmetalation transition structures for the transmetalation pathways of $\mathrm{Ag}\left(\mathrm{BPh}_{4}\right)_{2}{ }^{-}$(left, cf. Figure 2) and $\mathrm{Ag}_{2}\left(\mathrm{BPh}_{4}\right)^{+}$(middle, cf. Figure 2 and right, cf. Figure S10) obtained from PBEh-3c geometry optimizations. $\mathrm{H}$ atoms are omitted for clarity. 


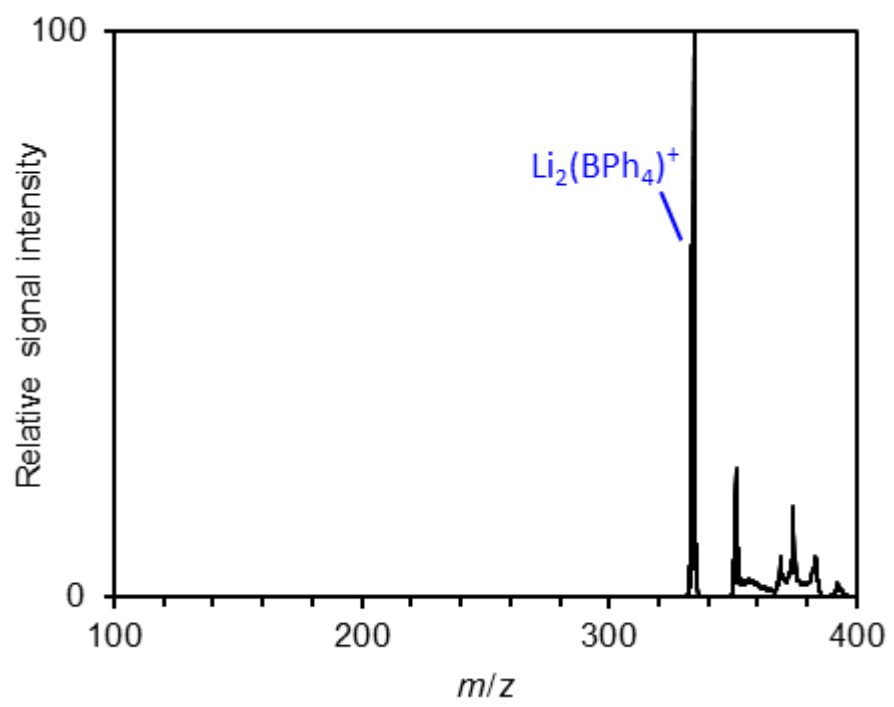

Figure S13. Mass spectrum of mass-selected $\mathrm{Li}_{2}\left(\mathrm{BPh}_{4}\right)^{+}(\mathrm{m} / z 333)$ upon collision-induced dissociation $\left(V_{\text {exc }}=1.50 \mathrm{~V}\right)$. Only loss of signal occurred, with no fragment ions being detected. The high excitation voltage and, thus, high collision energy applied resulted in only low signal intensities and a correspondingly high noise level.

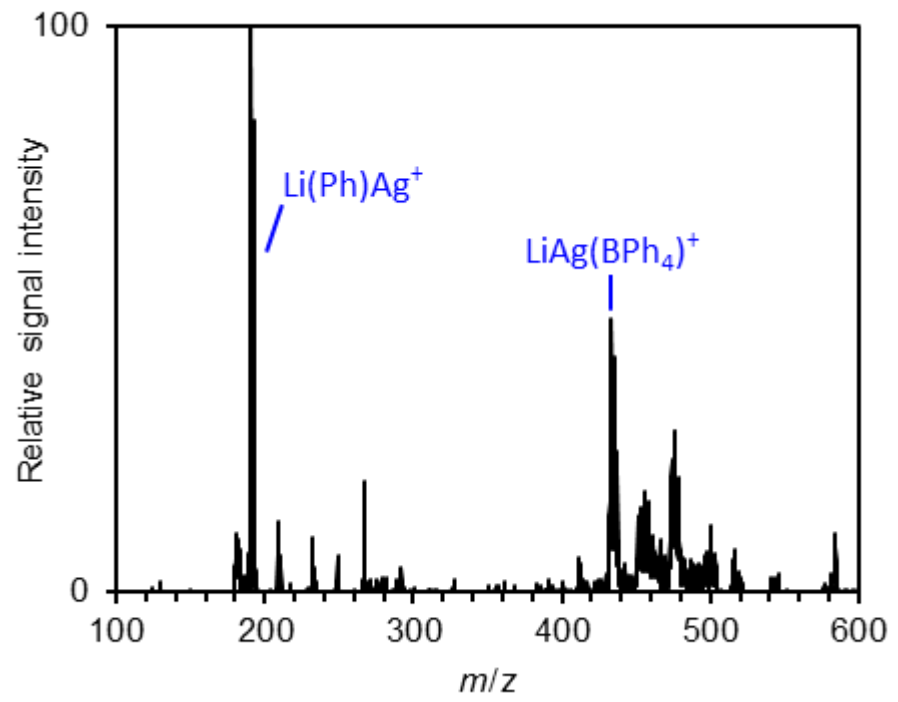

Figure S14. Mass spectrum of mass-selected $\mathrm{LiAg}\left(\mathrm{BPh}_{4}\right)^{+}(\mathrm{m} / z 434)$ and its fragment ions produced upon collision-induced dissociation $\left(V_{\mathrm{exc}}=0.80 \mathrm{~V}\right)$. The high excitation voltage and, thus, high collision energy applied resulted in only low signal intensities and a correspondingly high noise level. 


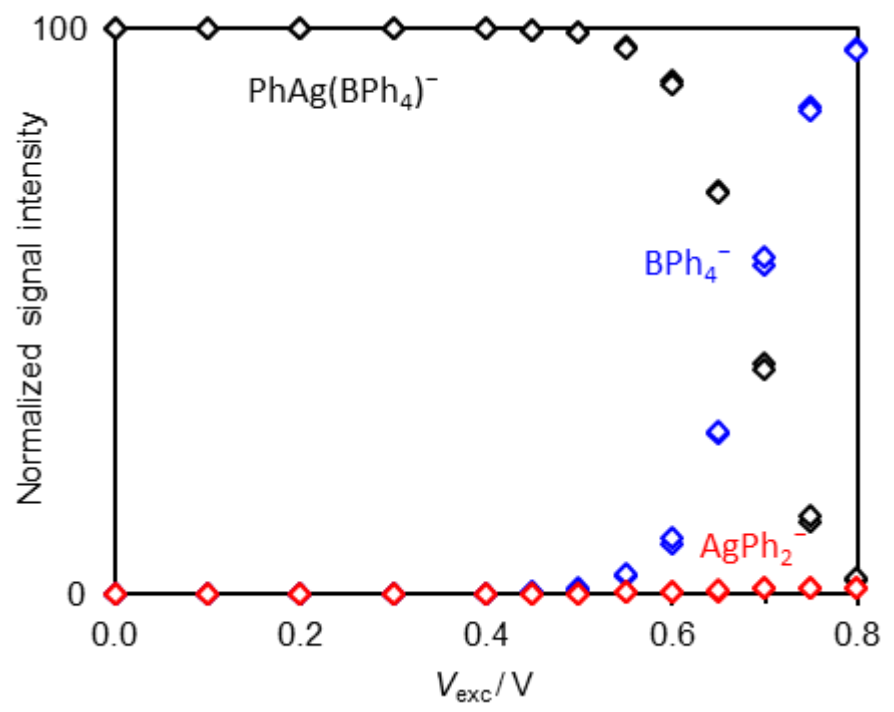

Figure S15. Normalized signal intensities of $\mathrm{PhAg}\left(\mathrm{BPh}_{4}\right)^{-}$and its fragment ions as function of the excitation voltage $V_{\text {exc }}$.

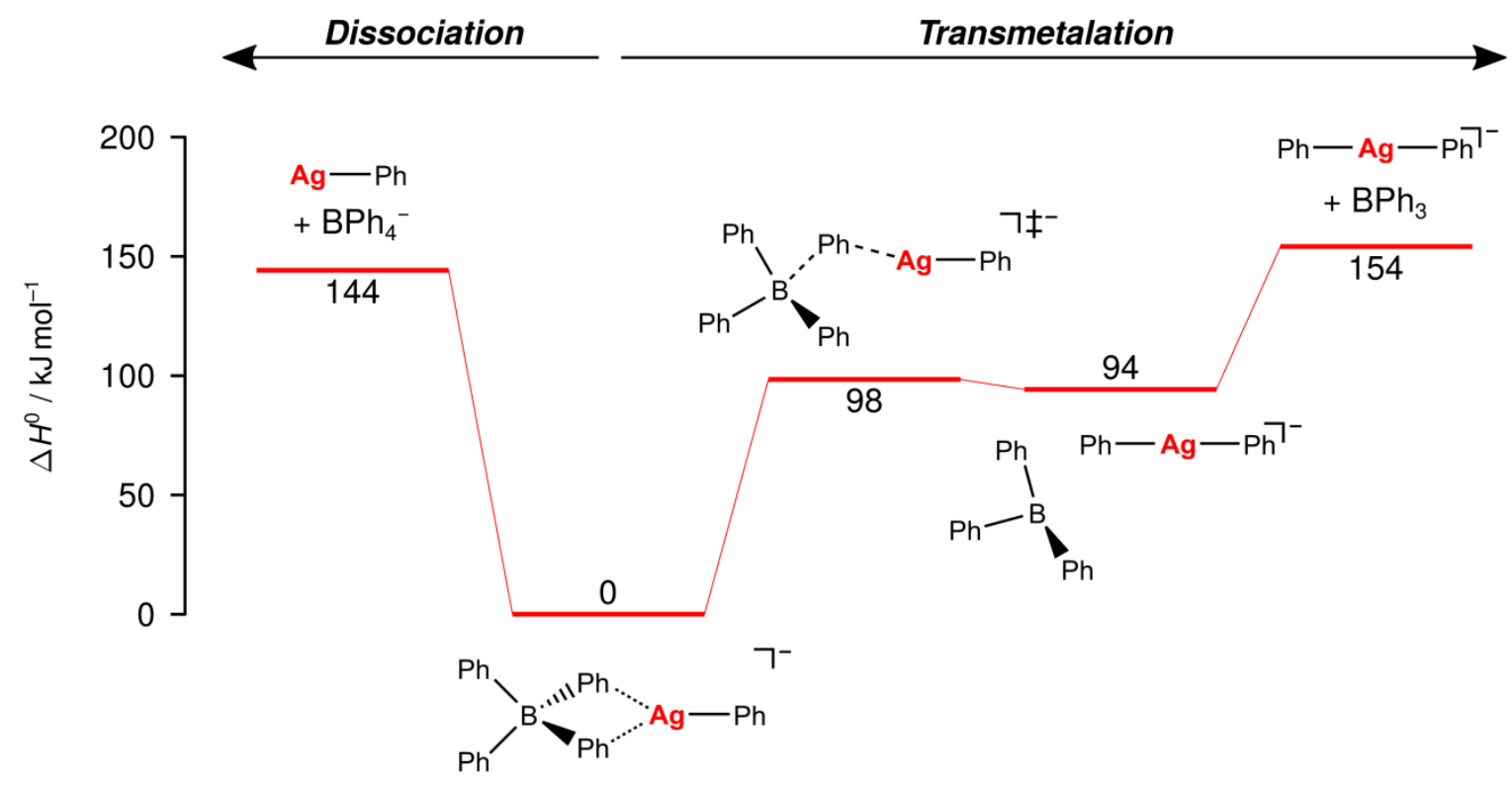

Figure S16. Energy diagram for the unimolecular reactivity (transmetalation vs. dissocation) of $\mathrm{PhAg}\left(\mathrm{BPh}_{4}\right)^{-}$ obtained from DSD-PBEP86-D3BJ/maug-cc-pVTZ//PBEh-3c calculations. 

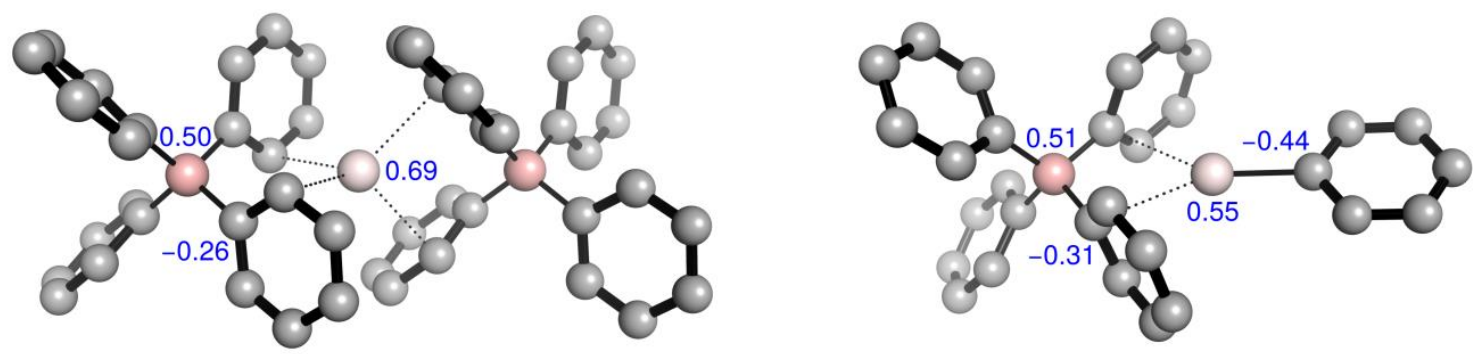

Figure S17. Molecular structures of $\mathrm{Ag}\left(\mathrm{BPh}_{4}\right)_{2}^{-}$(left) and $\mathrm{PhAg}\left(\mathrm{BPh}_{4}\right)^{-}$(right) obtained from $\mathrm{PBEh}-3 \mathrm{c}$ geometry optimizations. NPA charges for selected atoms from PBE0/cc-pVDZ/ECP28MDF calculations are shown in blue. $\mathrm{H}$ atoms are omitted for clarity.
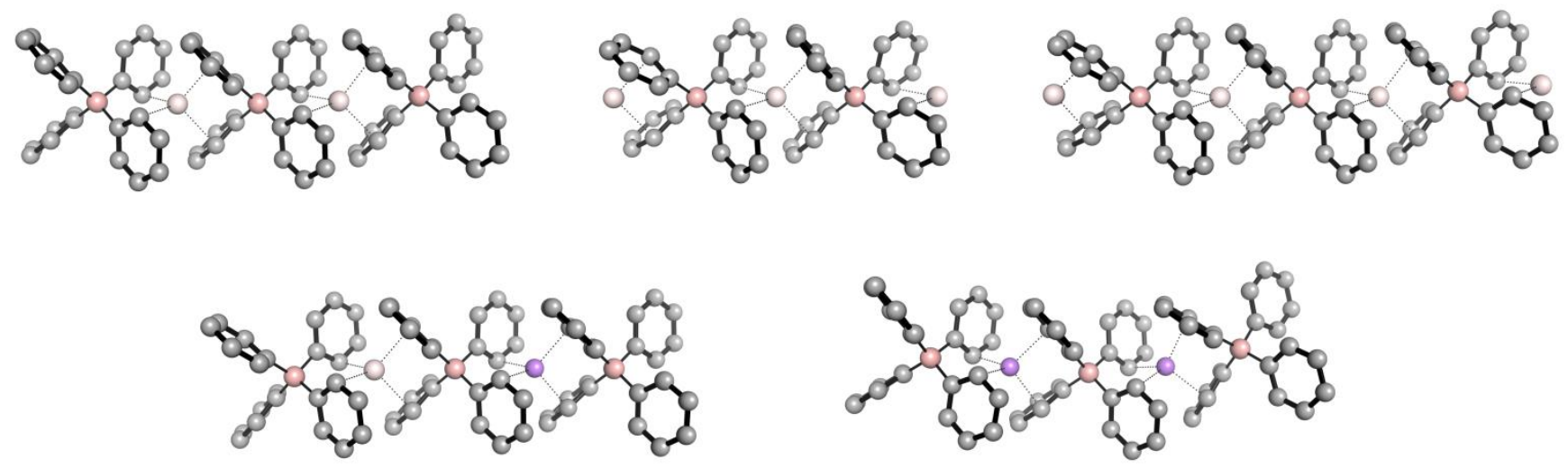

Figure S18. Molecular structures of $\mathrm{Ag}_{2}\left(\mathrm{BPh}_{4}\right)_{3}{ }^{-}$(top left), $\mathrm{Ag}_{3}\left(\mathrm{BPh}_{4}\right)_{2}{ }^{+}$(top middle), $\mathrm{Ag}_{4}\left(\mathrm{BPh}_{4}\right)_{3}{ }^{+}$(top right), $\mathrm{LiAg}\left(\mathrm{BPh}_{4}\right)_{3}{ }^{-}$(bottom left) and $\mathrm{Li}_{2}\left(\mathrm{BPh}_{4}\right)_{3}{ }^{-}$(bottom right) obtained from hybrid DFT geometry optimizations. The PBEh-3c method was used for $\mathrm{Ag}_{3}\left(\mathrm{BPh}_{4}\right)_{2}{ }^{+}$and the PBE0-D3BJ/def2-SVP approach for the other species. $\mathrm{H}$ atoms are omitted for clarity. 


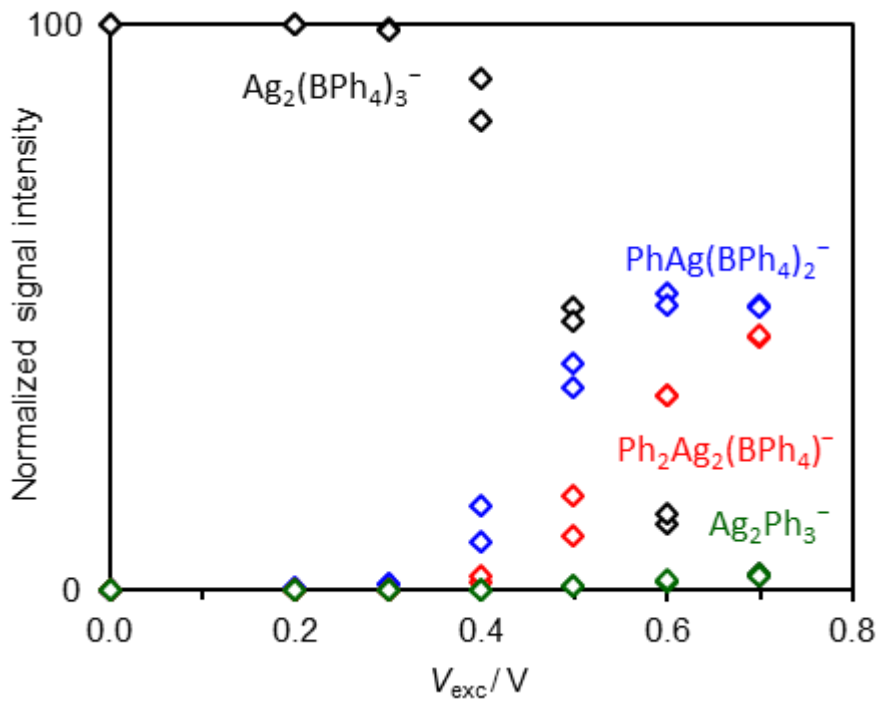

Figure S19. Normalized signal intensities of $\mathrm{Ag}_{2}\left(\mathrm{BPh}_{4}\right)_{3}{ }^{-}$and its fragment ions as function of the excitation voltage $V_{\text {exc }}$.

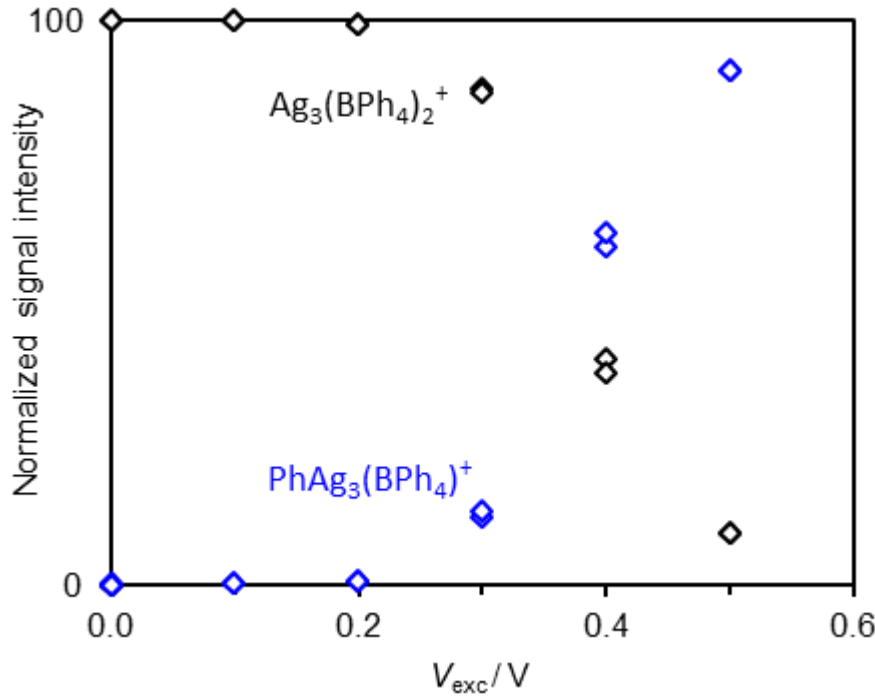

Figure S20. Normalized signal intensities of $\mathrm{Ag}_{3}\left(\mathrm{BPh}_{4}\right)_{2}^{+}$and its fragment ions as function of the excitation voltage $V_{\text {exc }}$. 


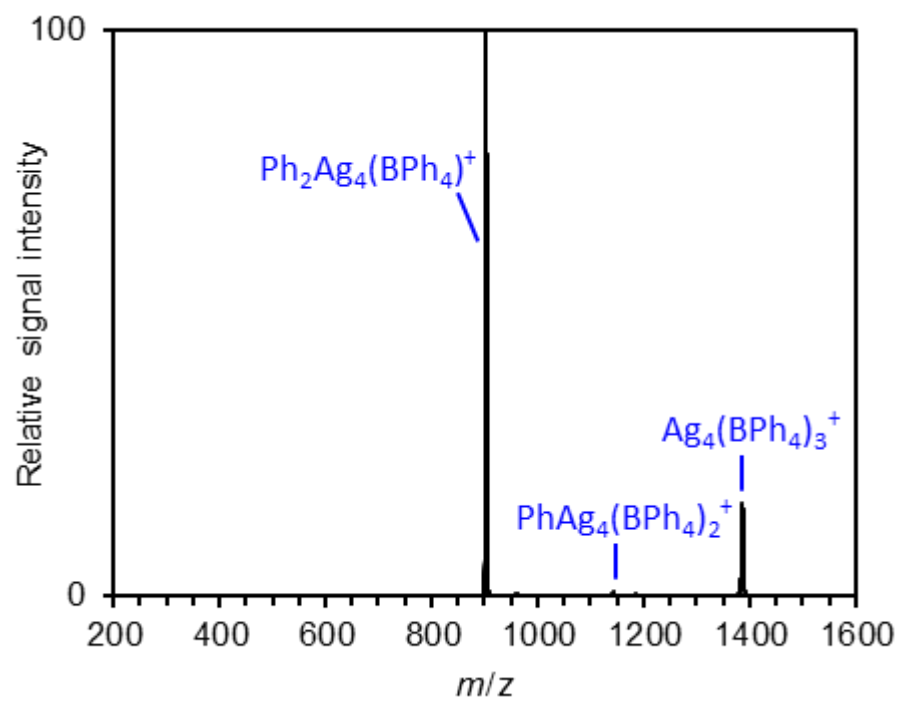

Figure S21. Mass spectrum of mass-selected $\mathrm{Ag}_{4}\left(\mathrm{BPh}_{4}\right)_{3}{ }^{+}(\mathrm{m} / z$ 1386) and its fragment ions produced upon collision-induced dissociation $\left(V_{\mathrm{exc}}=0.40 \mathrm{~V}\right)$.

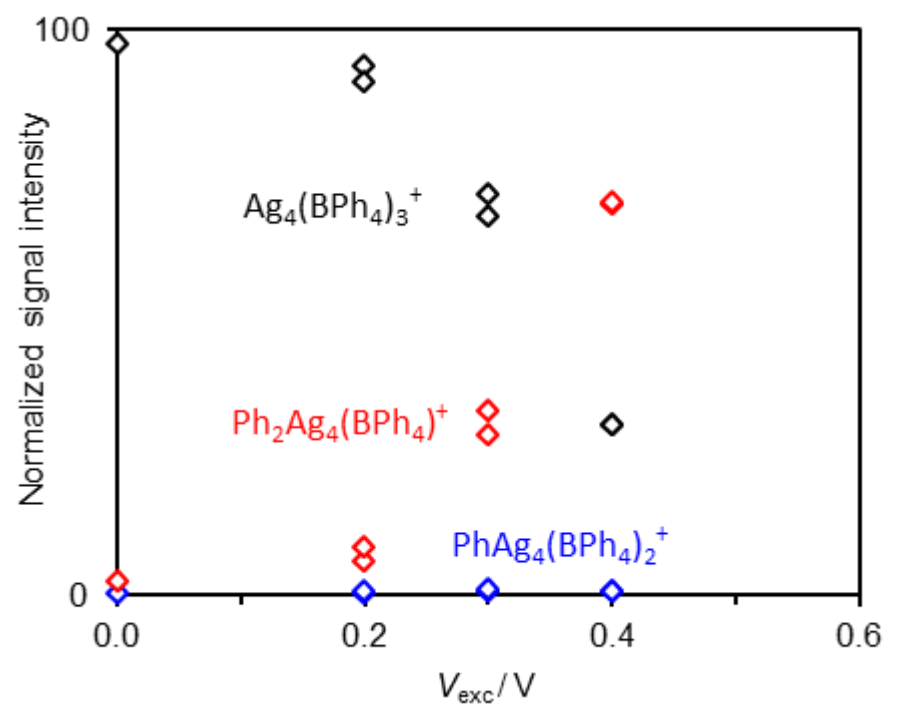

Figure S22. Normalized signal intensities of $\mathrm{Ag}_{4}\left(\mathrm{BPh}_{4}\right)_{3}{ }^{+}$and its fragment ions as function of the excitation voltage $V_{\text {exc. }}$. 


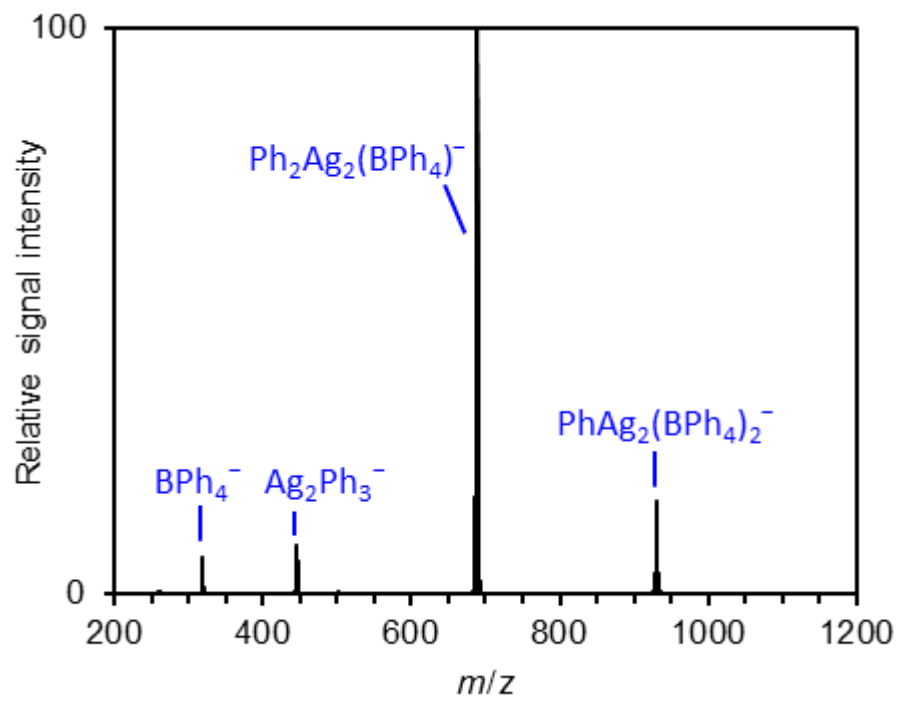

Figure S23. Mass spectrum of mass-selected $\mathrm{PhAg}_{2}\left(\mathrm{BPh}_{4}\right)_{2}^{-}(\mathrm{m} / z$ 931) and its fragment ions produced upon collision-induced dissociation $\left(V_{\mathrm{exc}}=0.60 \mathrm{~V}\right)$.

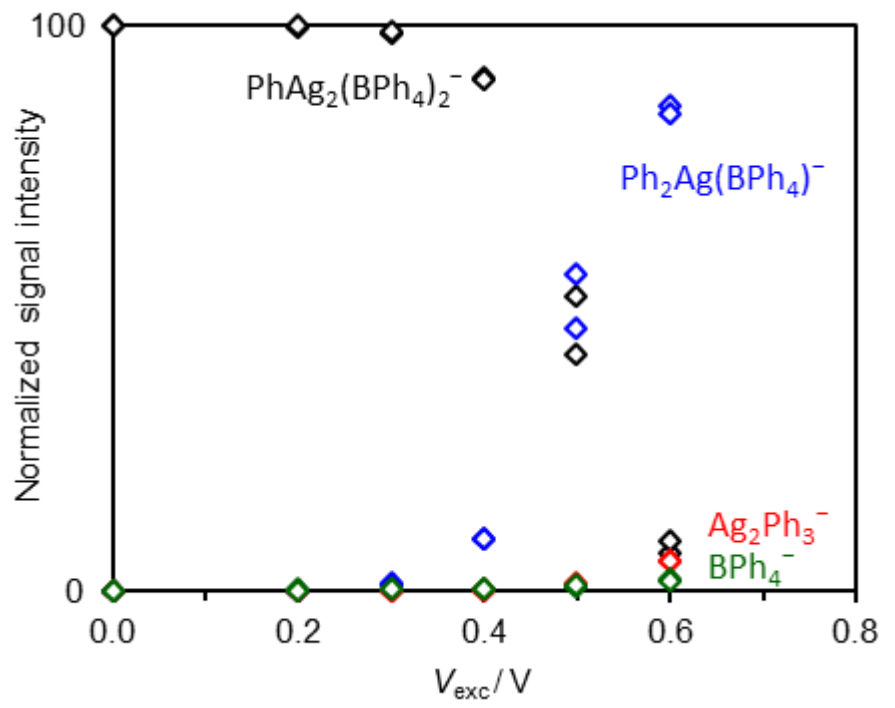

Figure S24. Normalized signal intensities of $\mathrm{PhAg}_{2}\left(\mathrm{BPh}_{4}\right)_{2}^{-}$and its fragment ions as function of the excitation voltage $V_{\text {exc. }}$. 


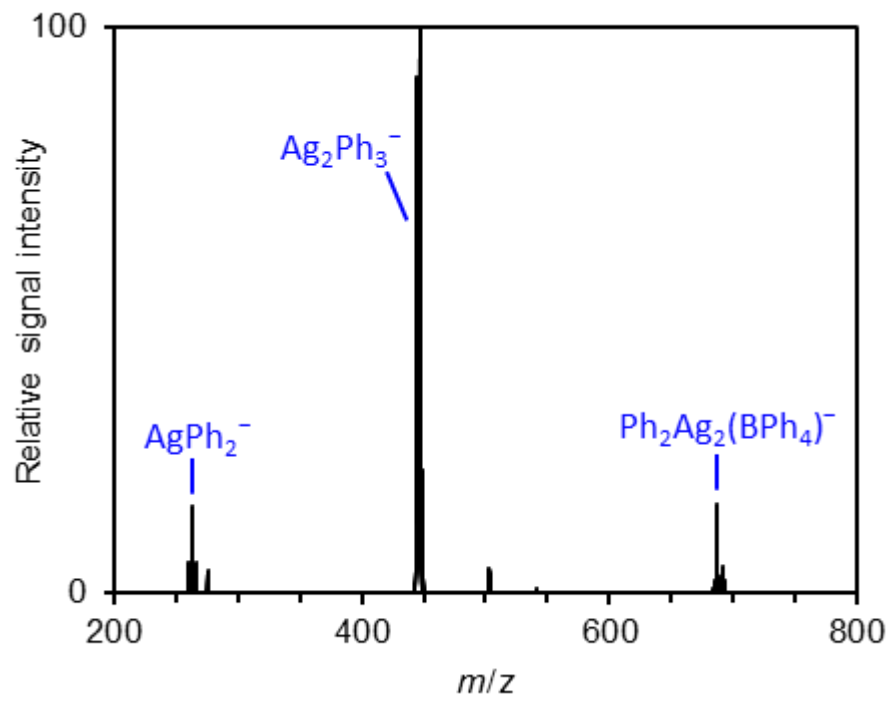

Figure S25. Mass spectrum of mass-selected $\mathrm{Ph}_{2} \mathrm{Ag}_{2}\left(\mathrm{BPh}_{4}\right)^{-}(\mathrm{m} / z$ 689) and its fragment ions produced upon collision-induced dissociation $\left(V_{\mathrm{exc}}=0.60 \mathrm{~V}\right)$.

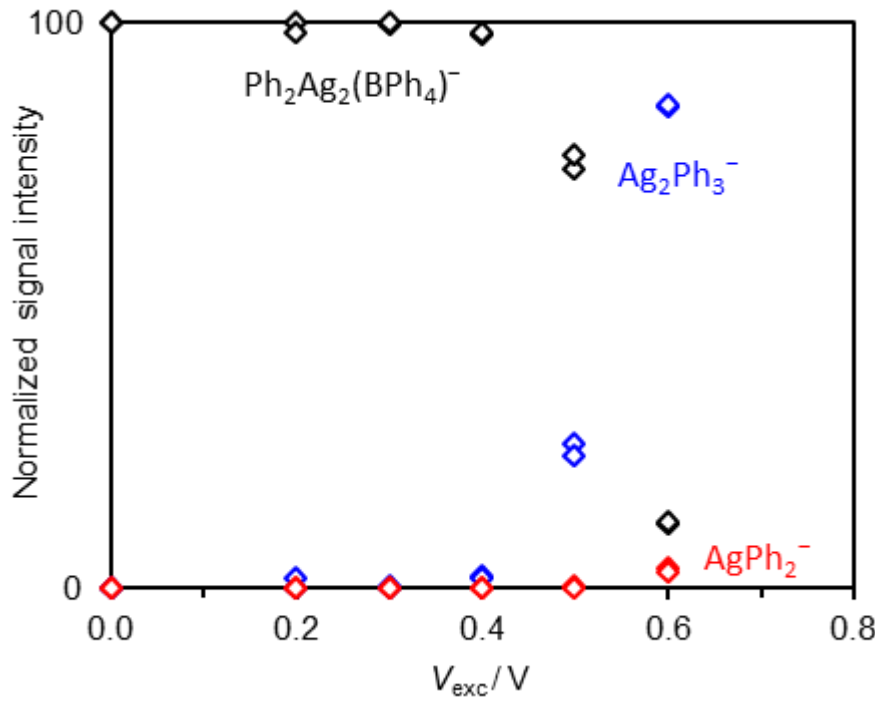

Figure S26. Normalized signal intensities of $\mathrm{Ph}_{2} \mathrm{Ag}_{2}\left(\mathrm{BPh}_{4}\right)^{-}$and its fragment ions as function of the excitation voltage $V_{\text {exc }}$. 


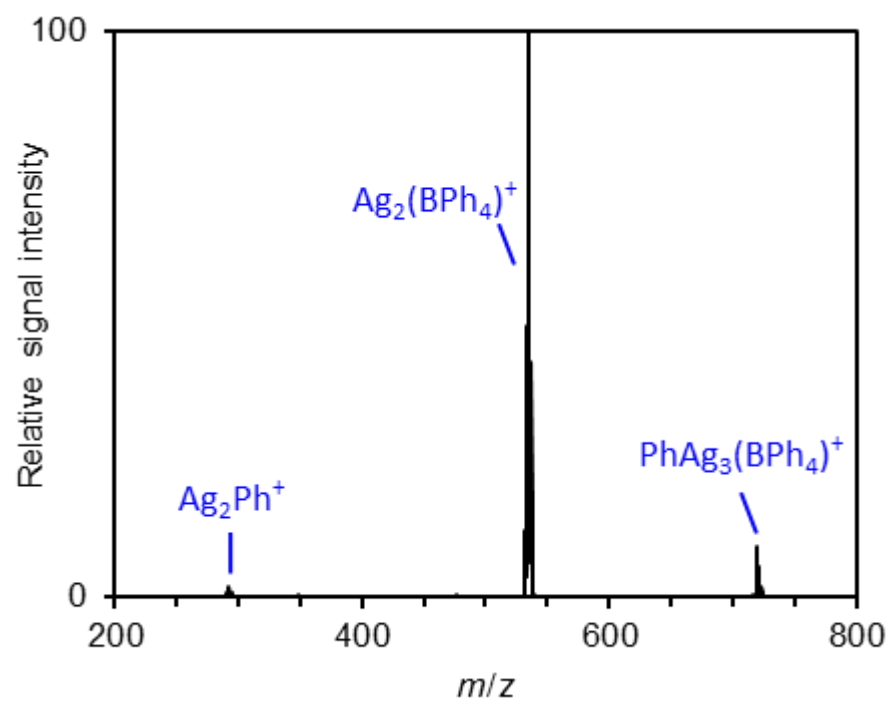

Figure S27. Mass spectrum of mass-selected $\mathrm{PhAg}_{3}\left(\mathrm{BPh}_{4}\right)^{+}(\mathrm{m} / z 719)$ and its fragment ions produced upon collision-induced dissociation $\left(V_{\mathrm{exc}}=0.75 \mathrm{~V}\right)$.

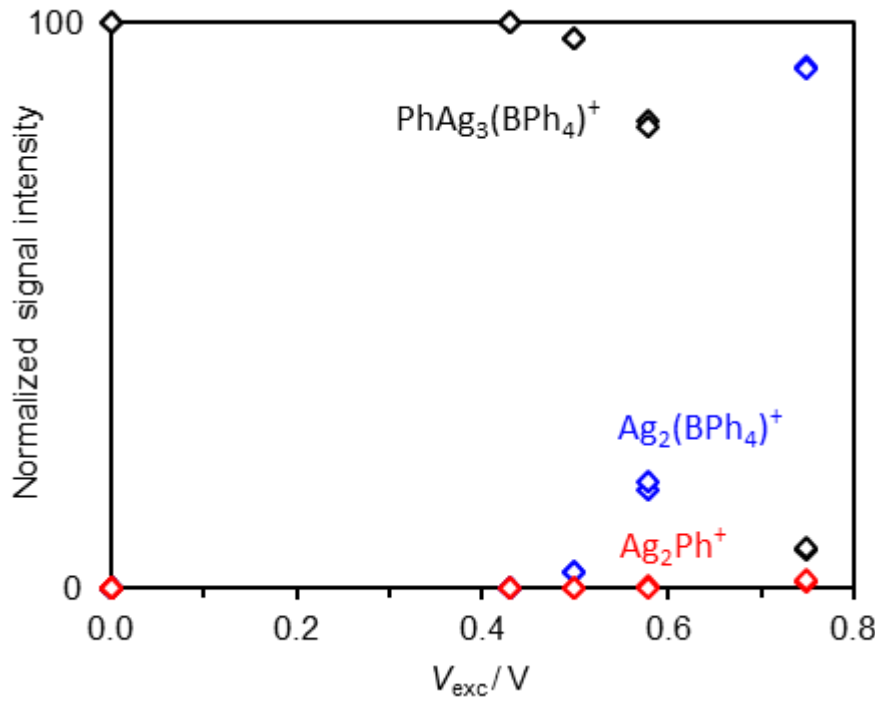

Figure S28. Normalized signal intensities of $\mathrm{PhAg}_{3}\left(\mathrm{BPh}_{4}\right)^{+}$and its fragment ions as function of the excitation voltage $V_{\text {exc }}$. 


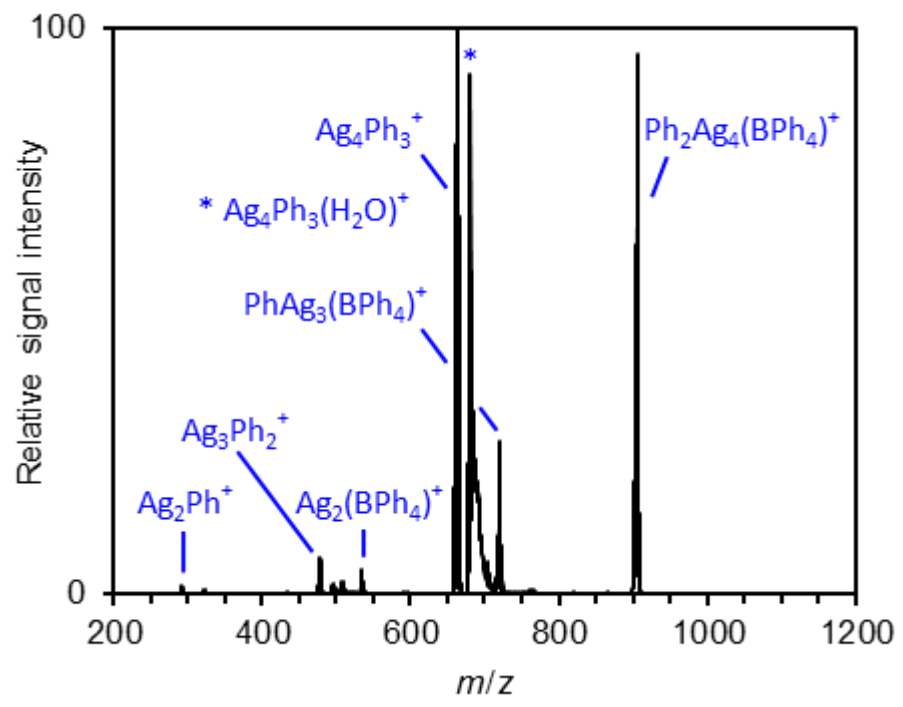

Figure S29. Mass spectrum of mass-selected $\mathrm{Ph}_{2} \mathrm{Ag}_{4}\left(\mathrm{BPh}_{4}\right)^{+}(\mathrm{m} / z 905)$ and its fragment ions produced upon collision-induced dissociation $\left(V_{\text {exc }}=0.80 \mathrm{~V}\right)$. The ion of a stoichiometry of $\mathrm{Ag}_{4} \mathrm{Ph}_{3}\left(\mathrm{H}_{2} \mathrm{O}\right)^{+}$resulted from an ionmolecule reaction with traces of background water present in the ion trap. 

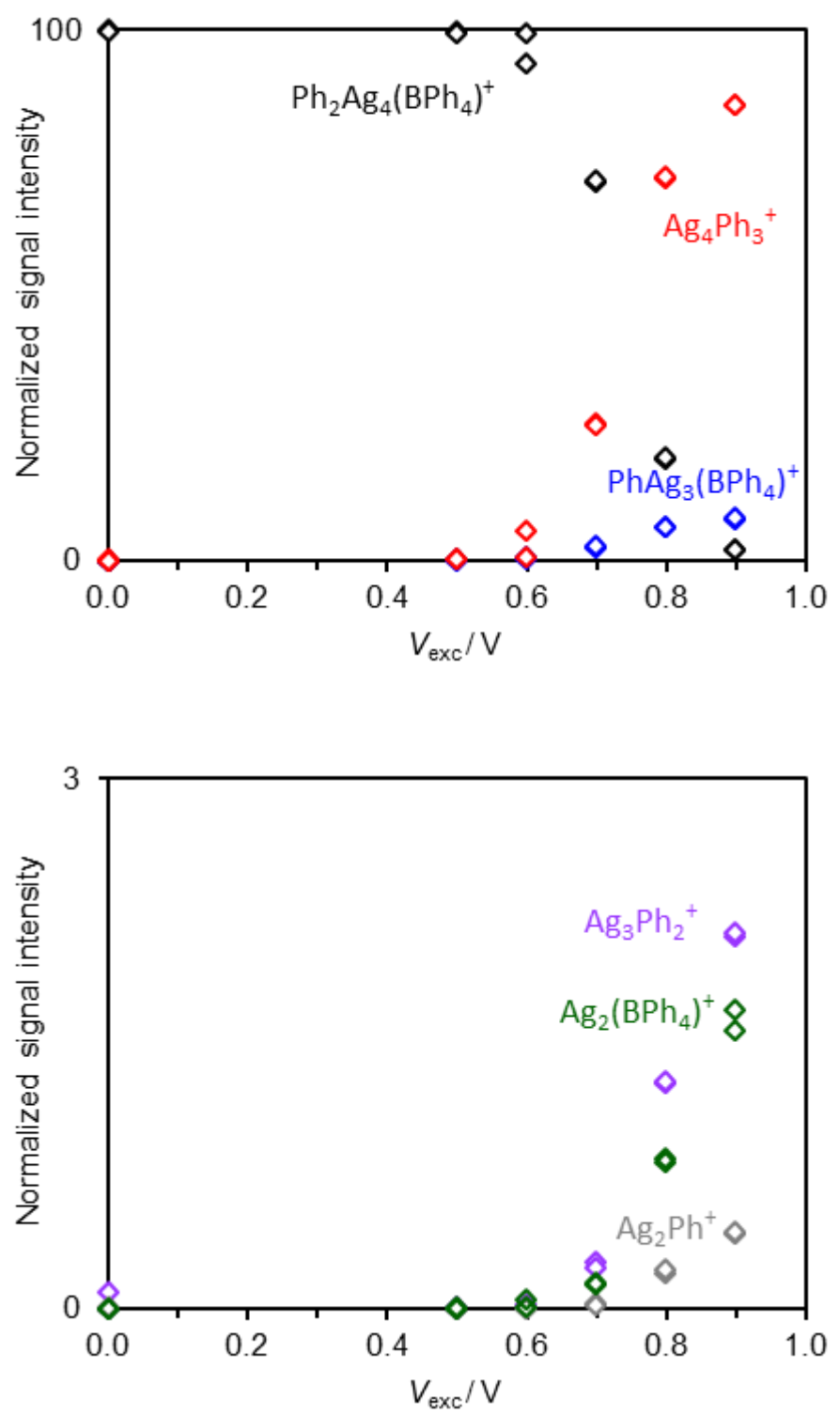

Figure S30. Top: Normalized signal intensities of $\mathrm{Ph}_{2} \mathrm{Ag}_{4}\left(\mathrm{BPh}_{4}\right)^{+}$and its major fragment ions as function of the excitation voltage $V_{\text {exc }}$. Bottom: Normalized signal intensities of the minor fragment ions of $\mathrm{Ph}_{2} \mathrm{Ag}_{4}\left(\mathrm{BPh}_{4}\right)^{+}$as function of the excitation voltage $V_{\text {exc }}$. 


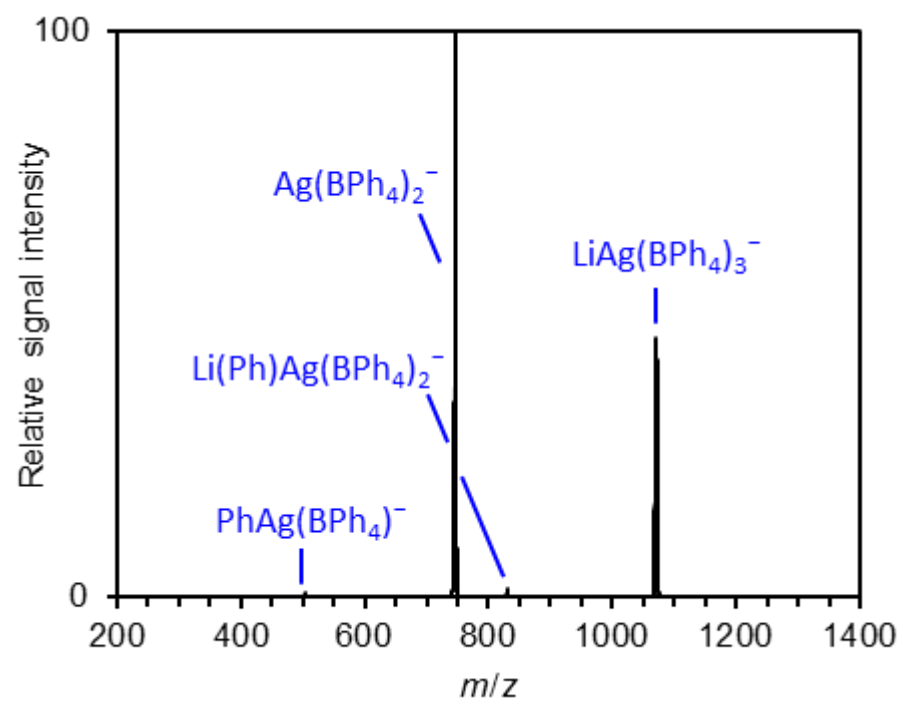

Figure S31. Mass spectrum of mass-selected $\mathrm{LiAg}\left(\mathrm{BPh}_{4}\right)_{3}{ }^{-}(\mathrm{m} / \mathrm{z} 1071)$ and its fragment ions produced upon collision-induced dissociation $\left(V_{\mathrm{exc}}=0.40 \mathrm{~V}\right)$.

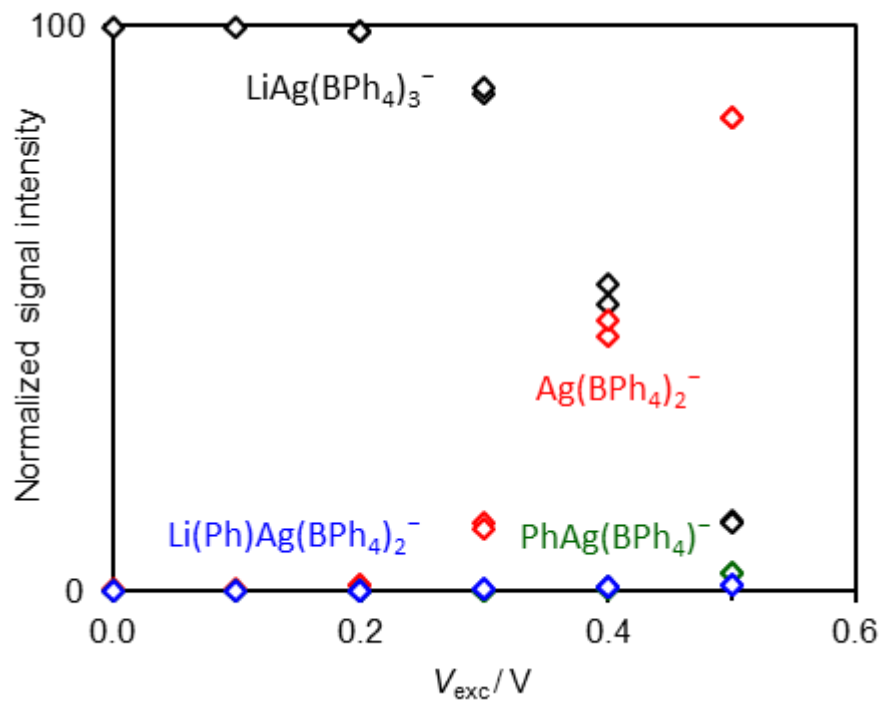

Figure S32. Normalized signal intensities of $\mathrm{LiAg}\left(\mathrm{BPh}_{4}\right)_{3}{ }^{-}$and its fragment ions as function of the excitation voltage $V_{\text {exc. }}$. 


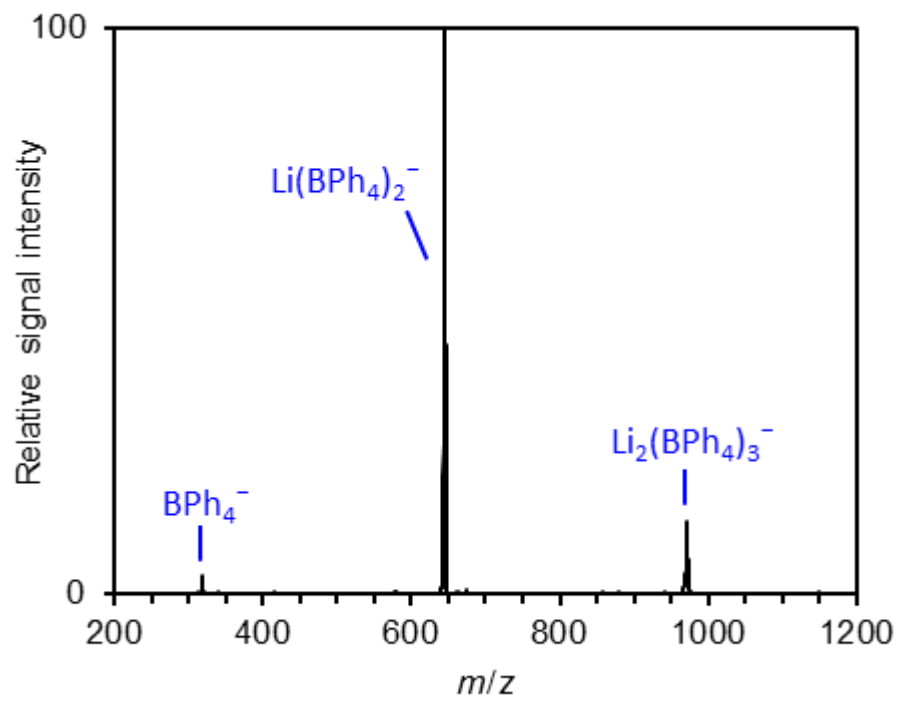

Figure S33. Mass spectrum of mass-selected $\mathrm{Li}_{2}\left(\mathrm{BPh}_{4}\right)_{3}{ }^{-}(\mathrm{m} / z 971)$ and its fragment ions produced upon collision-induced dissociation $\left(V_{\mathrm{exc}}=0.50 \mathrm{~V}\right)$.

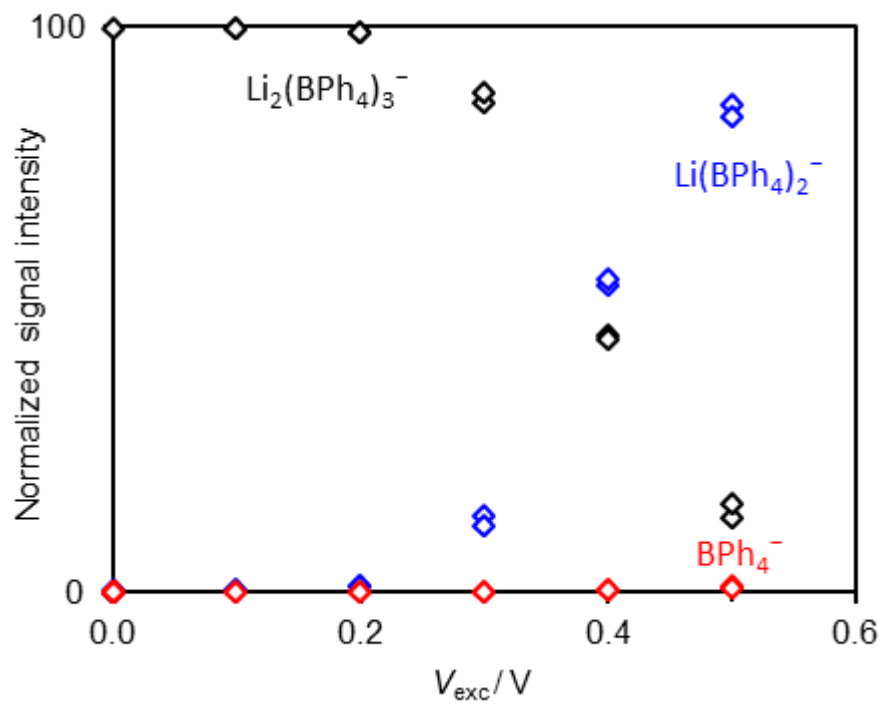

Figure S34. Normalized signal intensities of $\mathrm{Li}_{2}\left(\mathrm{BPh}_{4}\right)_{3}{ }^{-}$and its fragment ions as function of the excitation voltage $V_{\text {exc }}$. 


\section{3) Author contributions}

T.A.: $\quad$ Quantum chemical calculations and data analysis: lead

NMR experiments and data analysis: lead

ESI-mass spectrometric experiments and data analysis: supporting

Writing of original draft: equal

K.K.: $\quad$ ESI-mass spectrometric experiments and data analysis: lead

Writing of original draft: equal

Design of study: equal

R.A.J.O.: $\quad$ ESI-mass spectrometric experiments and data analysis: supporting

Writing of original draft: equal

Design of study: equal

All authors contributed to the final manuscript. 